\title{
Fungsi Partai Politik dalam Memberikan Pendidikan Politik Bagi Masyarakat
}

\author{
Masriyani $^{1}$, Herma Yanti ${ }^{2}$ \\ Fakultas Hukum Universitas Batanghari \\ Email: masriyani@unbari.ac.id
}

\begin{abstract}
Abstrak. Demokrasi merupakan pemerintahan oleh rakyat, yang dimaknai sebagai suatu yang paling mendasar. sebagaimana diatur dalam pasal 28 UUD 1945, yang menyatakan bahwa : "kemerdekaan Berserikat dan berkumpul,mengeluarkan pikiran dengan lisan dan tulisan dan sebagainya ditetapkan dengan undang-undang."Salah satu media untuk mengaplikasikan pasal 28 tersebut, dapat disalurkan melalui partai politik. Penelitian ini merupakan penelitian dalam spesifikasi yuridis normative, tentang fungsi partai politik terhadap pendidikan politik Bagi masyarakat dan konsekuensi yuridisnya, yang mana secara norma telah diatur dalam Undang-Undang Nomor 2 Tahun 2011. Adapun permasalahan yang dibahas adalah bagimana pengaturan hukum dari fungsi partai politik terkait pendidikan politik pada masyarakat. Hasil penelitian menunjukan bahwa di dalam Undang-Undang Nomor 2 Tahun 2011 telah diatur bahwa fungsi parpol salah satunya adalah melaksanakan pendidikan politik pada masyarakat. Dimana pengaturan lebih lanjut dari UU tersebut adalah dibentuknya PP nomor 1 Tahun 2018 yang didalamnya memberikan pengaturan terkait bantuan dana yang diprioritaskan untuk pelaksanaan pendidikan tersebut. Dari adanya bantuan dana baik dari APBN/APBD yang diterima partai politik, maka mengakibatkan konsekuensi yuridis atas pertanggungjawaban kepada Badan Pemeriksa Keuangan.
\end{abstract}

Kata kunci: demokrasi, partai politik, pendidikan politik

Abstract. Democracy is a government by the people, which is interpreted as the most basic. as stipulated in article 28 of the 1945 Constitution, which states that: "freedom of association and assembly, issuing thoughts by word and mouth and so forth is stipulated by law." One of the media to apply article 28 can be channeled through political parties. is a research in normative juridical specifications, about the functions of political parties on political education for the public and its juridical consequences, which are normatively regulated in Law No. 2 of 2011. The issues discussed are how to regulate the functions of political parties related to political education to the community. The results of the study show that in Law No. 2 of 2011 it has been regulated that the function of political parties is to carry out political education in the community. Where further regulation of the Act is the establishment of Government Regulation number 1 of 2018 in which it provides arrangements relating to priority funding assistance for the implementation of such education. From the existence of financial assistance both from the APBN / APBD received by political parties, it will result in juridical consequences for accountability to the Supreme Audit Agency.

Keywords: democracy, political parties, political education

\section{PENDAHULUAN}

Secara harfiah demokrasi adalah pemerintahan oleh rakyat, yang dapat pula dimaknai sebagai suatu yang paling mendasar dan paling luas didefeinisikan. Pembicaraan demokrasi pada beberapa negara berskala besar modern adalah bahwa tindakan yang dilakukan oleh pemegang kekuasaan negara biasanya tidak dilaksanakan secara langsung oleh warga negara melainkan melalui perwakilan yang mereka pilih secara

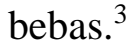

Pasal 1 ayat (2) UUD 1945 menjelaskan bahwa "Kedaulatan ada di tangan rakyat", dari pasal tersebut dapat dicermati bahwa negara Indonesia menganut faham demokrasi. Dan karena itulah dalam mengimplementasikan kedaulatan yang dimiliki oleh rakyat tersebut, salah satu cara yang tepat adalah melalui mekanisme pemilihan umum atau yang lebih dikenal dengan pemilu.

\footnotetext{
${ }^{1}$ Masriyani, Dosen Tetap Yayasan Pendidikan Jambi, Universitas Batanghari Program Studi Ilmu Hukum.

${ }^{2}$ Herma Yanti, Dosen Tetap Yayasan Pendidikan Jambi, Universitas Batanghari Program Studi Ilmu Hukum.

${ }^{3}$ Lihat Abdul Bari Azed, Pemilu dan Partai Politik Di Indonesia, Pusat Studi Hukum Tata Negara FH-UI, Jakarta, 2013,
} hal. 11. 
Selanjutnya dengan diamandemennya UUD 1945, Pemilu disebutkan secara khusus dalam Bab VIIB. Ini menunjukan bahwa pemilu sangat berkaitan erat dengan sistem ketatanegaraan Indonesia terutama dalam pemenuhan keanggotaan lembaga negara DPR, DPD , Presiden dan Wakil Presiden sebagaimana tercantum dalam beberapa pasal dalam UUD 1945.

Dapat dipahami bahwa pemilihan umum merupakan unsur yang sangat penting dalam sebuah negara demokrasi, dimana pelaksanaan dari pemilihan umum ini adalah salah satu wujud nyata dari hak asasi warga negara dalam mengeluarkan pendapatnya, ide dan pemikirannya untuk memilih wakil wakil mereka yang dianggap cakap dalam memimpin negaranya dan menyalurkan kepentingannya, sebagaimana diatur dalam pasal 28 UUD 1945, yang menyatakan bahwa : "kemerdekaan Berserikat dan berkumpul,mengeluarkan pikiran dengan lisan dan tulisan dan sebagainya ditetapkan dengan undang-undang."

Salah satu media untuk mengaplikasikan pasal 28 tersebut, dapat disalurkan melalui partai politik. Partai politik merupakan wadah bagi masyarakat untuk berkumpul, menyalurkan aspirasi, dan pendapat politik yang memungkinkan untuk membangun negara. Sebagaimana dijelaskan Abdul Bari Azed bahwa:

kegiatan seseorang dalam partai politik merupakan suatu bentuk partisipasi politik. Partisipasi politik mencakup semua kegiatan sukarela melalui mana seseorang turut serta secara langsung atau tidak langsung dalam pembentukan kebijaksanaan umum, menjadi anggota dalam golongan politik seperti partai, kelompok penekan (pressure group), Kelompok kepentingan (interest group), duduk dalam lembaga politik seperti Dewan Perwakilan Rakyat atau mengadakan komunikasi dengan wakil-wakil rakyat yang duduk dalam badan-badan itu, berkampanye, menghadiri kelompok diskusi dan sebagainya. ${ }^{4}$

Di Indonesia peran Partai Politik adalah sebagai pilar penyangga demokrasi. Dalam artian bahwa, keberadaan demokrasi tanpa adanya Partai Politik adalah sebuah situasi kekuasaan tanpa legitimasi. Karena begitu pentingnya peran Partai Politik, maka sudah selayaknya jika Partai Politik diharapkan mampu menjamin demokrasi yang sehat dan efektif dengan menciptakan kondisi Partai Politik yang sehat dan efektif, maka memungkinkan untuk melaksanakan rekrutmen pemimpin atau proses pengkaderan, pendidikan politik dan kontrol sosial yang sehat.

Saat ini sistem politik Indonesia telah menempatkan partai politik sebagai salah satu pilar penyangga demokrasi. Kehadiran partai politik dalam Negara demokrasi tidak dapat dilepaskan dari peran dan fungsinya, tidak hanya kepada konstituen yang dikelola tetapi juga kepada bangsa dan negara. Baik buruknya sebuah partai politik akan berdampak pada baik buruknya sebuah bangsa. Hal ini karena jabatanjabatan dalam sebuah negara nantinya akan diisi oleh orang-orang dari partai politik yang ada melalui pemilu.

Dengan Partai Politik pula, konflik dan konsensus dapat tercapai guna mendewasakan masyarakat. Konflik yang tercipta tidak lantas dijadikan alasan untuk memecah belah partai, tapi konflik yang timbul dicarikan konsensus guna menciptakan partai yang sehat dan fungsional.

Partai politik merupakan sarana atau wadah bagi masyarakat untuk berkumpul, menyalurkan aspirasi, dan pendapat politik yang memungkinkan untuk membangun negara. Saat ini sistem politik Indonesia telah menempatkan partai politik sebagai salah satu pilar penyangga demokrasi. Kehadiran partai politik dalam negara demokrasi tidak dapat dilepaskan dari peran dan fungsinya, tidak hanya kepada konstituen yang dikelola tetapi juga kepada bangsa dan negara. Baik buruknya sebuah bangsa. Hal ini karena jabatan-jabatan dalam sebuah negara nantinya akan diisi oleh orang-orang dari partai politik yang ada melalui pemilu.

Dalam rangka pelaksanaan sistem Negara yang demokrasi untuk dapat mewujudkan kesejahteraan masyarakat, diperlukan partai politik (parpol) yang merupakan sarana partisipasi politik masyarakat dalam mengembangkan kehidupan demokrasi untuk menjujung tinggi kebebasan yang bertanggung jawab. Parpol merupakan wadah bagi masyarakat untuk mengekspresikan serta mengaktualisasikan haknya dalam mengeluarkan pendapat, berkumpul, dan berserikat sebagai hak asasi manusia dalam rangka mewujudkan kehidupan kebangsaan yang kuat sebagaimana disebutkan dalam pasal 28 E ayat 3 UUD 1945 bahwa setiap orang berhak atas kebebasan berserikat, berkumpul dan mengeluarkan pendapat.

\footnotetext{
${ }^{4}$ Abdul Bari Azed, Pemilu dan Partai Politik Di Indonesia,Pusat Studi Hukum Tata Negara FH-UI, Jakarta, 2013, hal.
} 
Fungsi Parpol sebagaimana disebut dalam pasal 11 ayat 1 UU No 2 tahun 2011 tentang partai politik antara lain sebagai sarana pendidikan bagi masyarakat luas agar menjadi warga Negara Indonesia yang sadar akan hak dan kewajibannya dalam kehidupan masyarakat. Banyak parpol di Indonesia membawa konsekuensi bahwa seharusnya masyarakat pemilih mempunyai wawasan yang lebih luas tentang hal yang terkait dengan kebebasan berdemokrasi. Namun demikian, sampai saat ini peran parpol dalam memberikan pendidikan politik bagi masyarakat masih belum terasa maksimal diterima, yang menjadi kelemahannya yaitu belum adanya pemberian reward and punishment bagi suatu parpol yang tidak memberikan pendidikan politik kepada warga Negara.

Kurang terdidiknya warga negara secara politik, telah menyebabkan mereka cenderung pasif dan mudah dimobilisasi untuk kepentingan pribadi/jabatan dari para elite politik. Lebih dari itu, mereka juga tidak bisa ikut mempengaruhi secara signifikan proses-proses pengambilan keputusan yang berkaitan erat dengan kehidupan mereka. Pada hal, sudah menjadi rahasia umum bahwa proses demokratisasi yang sehat mensyaratkan adanya partisipasi politik yang otonom dari warga negara. Partisipasi politik yang otonom ini, hanya dapat dimungkinkan jika warga negara cukup terdidik secara politik.

Pendidikan politik bagi masyarakat sangat diperlukan agar mereka dapat menentukan pilihan politiknya secara cerdas dan untuk menjamin kualitas hasil pemilukada. dalam konteks pranata masyarakat modern yang demokratis,pemilu merupakan alat legal formal bagi rakyat untuk memilih wakil yang akan merepresentasikan kepentingannya, ${ }^{5}$ Memilih dan dipilih adalah salah satu hak asasi bagi manusia, untuk itu parpol adalah salah satu pilar demokrasi yang idealnya memberikan pendidikan politik dan pencerahan kepada rakyat sebagai konstituennya.

Pentingnya pendidikan politik yang dilaksanakan oleh partai politik secara maksimal dan pada esensi yang sebenarnya akan dapat memberikan dampak yang sangat baik bagi masyarakat, maksudnya masyarakat mampu menjadi orang yang sadar akan kewajiban mereka serta yang paling penting dalam pelaksanaan pendidikan politik yaitu masyarakat menjadi sadar dan menjadi orang yang pintar dalam memberikan pilihan kepada partai politik atau calon yang benar dan tulus dalam hal kesejahteraan rakyat. Pelaksanaan pendidikan politik ini,selain dapat dilakukan oleh pemerintah melalui lembaga-lembaga pendidikan formal yang ada,juga bisa dilaksanakan secara non-formal oleh organisasi-organisasi masyarakat sipil untuk menumbuhkan dan meningkatkan partisipasi politik yang otonom dari setiap warga negara.

Dalam pelaksanaan fungsinya sebagai sarana pendidikan politik menurut Undang-Undang Nomor 2 Tahun 2011 partai politik berhak memperoleh bantuan keuangan yang bersumber dari Anggaran Pendapatan dan Belanja Negara / Anggaran Pendapatan dan Belanja Daerah yang diberikan secara proporsional kepada partai politik yang mendapatkan kursi di Dewan Perwakilan Rakyat, Dewan Perwakilan Rakyat Daerah Provinsi, dan Dewan Perwakilan Rakyat Daerah Kabupaten/Kota yang perhitungannya berdasarkan jumlah perolehan suara. Pemerintah mengeluarkan Peraturan Pemerintah Nomor 83 Tahun 1982 tentang Perubahan atas Peraturan Pemerintah Nomor 5 Tahun 2009 tentang Bantuan Keuangan kepada Partai Politik yang diundangkan dan mulai berlaku pada tanggal 17 Oktober 1982.

Pasal 12 A ayat (1) dan Pasal 18 A Peraturan Pemerintah tersebut mengamanatkan kepada BPK RI untuk membuat Peraturan BPK mengenai Tata Cara Penyampaian Laporan oleh Partai Politik dan Tata Cara Penyampaian Laporan Hasil Pemeriksaan oleh BPK kepada partai politik, paling lama 1 (satu) tahun sejak Peraturan Pemerintah tersebut diundangkan.

Berbeda dengan PP Nomor 5 Tahun 2009 yang tidak memberikan batasan porsi penggunaan bantuan keuangan antara pendidikan politik dan operasional sekretariat partai politik, PP Nomor 83 Tahun 1982 memberi batasan bahwa bantuan keuangan kepada partai politik yang digunakan untuk melaksanakan pendidikan politik bagi anggota partai politik dan masyarakat paling sedikit $60 \%$ (enampuluh per seratus). Ini bearti bahwa fungsi partai politik dalam memberikan pendidikan politik pada masyarakat merupakan hal yang benar-benar harus dilaksanakan sesuai dengan amanat peraturan pemerintah tersebut, sehingga akan membantu mencerdaskan masyarakat dalam berdemokrasi.

Menurut Pasal 31 Undang-Undang Nomor 2 Tahun 2011 tujuan dari partai politik dalam melakukan pendidikan politik bagi masyarakat. Pertama, meningkatkan kesadaran hak dan kewajiban masyarakat dalam kehidupan bermasyarakat, berbangsa, dan bernegara. Kedua, meningkatkan partisipasi politik dan inisiatif

${ }^{5}$ Heru Nugroho,Pasar Dan Keadilan Sosial,2001,hlm 88, 
masyarakat dalam kehidupan bermasyarakat, berbangsa dan bernegara. Ketiga, meningkatkan kemandirian, kedewasaan, dan membangun karakter bangsa dalam rangka memelihara persatuan dan kesatuan bangsa. Dimana pendidikan politik tersebut dilaksanakan untuk membangun etika dan budaya politik sesuai dengan Pancasila.

Pada tataran ini pentingnya memberikan pendidikan politik kepada masyarakat sehingga masyarakat memahami apa artinya berdemokrasi dan mengerti akan pentingnya menggunakan hak pilih, pemerintah perlu membuat sanksi yang tegas bagi parpol yang tidak memberikan pendidikan politik kepada masyarakat melalui kegiatan-kegiatan budaya seminar, atau pada jalur pendidikan formal pada SLTA dan Perguruan Tinggi.

\section{Tinjauan Umum Demokrasi dan Partai Politik Demokrasi}

Secara etimologi, demokrasi berasal dari bahasa Yunani yaitu "demos" berarti rakyat dan "kratos/kratein" berarti pemerintahan atau kekuasaan. Jadi demokrasi berarti kekuasaan oleh rakyat atau government by the people.Menurut Kamus Hukum, demokrasi adalah bentuk pemerintahan yang didasarkan atas kerakyatan. ${ }^{6}$ Sementara itu dalam kamus Dictionary Websters mendefinisikan, demokrasi adalah pemerintahan oleh rakyat dimana kekuasaan tertinggi berada di tangan rakyat dan dijalankan langsung oleh mereka atau wakil-wakil yang mereka pilih di bawah sistem pemilihan umum yang bebas. ${ }^{7}$

Hendry B. Mayo memberikan pengertian tentang sistem politik demokratis adalah sistem yang menunjukkan bahwa kebijakan umum ditentukan atas dasar mayoritas oleh wakil-wakil yang diawasi secara efektif oleh rakyat dalam pemilihan berkala yang didasarkan atas prinsip kesamaan politik dan diselenggarakan dalam suasana terjaminnya kebebasan politik. ${ }^{8}$

Demokrasi pertama-tama merupakan gagasan yang mengandaikan bahwa kekuasaan itu adalah dari, oleh dan untuk rakyat.Dalam pengertian yang lebih partisipatif demokrasi itu bahkan disebut sebagai konsep kekuasaan dari, oleh, untuk dan berasal dari rakyat, dan karena itu rakyatlah yang sebenarnya menentukan dan memberi arah serta yang sesungguhnya menyelenggarakan kehidupan kenegaraan.Pada dasarnya juga diperuntukkan bagi seluruh rakyat itu sendiri.Bahkan negara yang baik diidealkan pula agar diselenggarakan bersama-sama dengan rakyat dalam arti dengan melibatkan masyarakat dalam arti yang seluas-luasnya.

Proklamasi kemerdekaan Indonesia 1 Agustus 1945 merupakan salah satu bukti bahwa Indonesia adalah negara demokrasi, seperti ditegaskan dalam naskah Proklamasi yaitu "Kami bangsa Indonesia dengan ini menyatakan kemerdekaan Indonesia". Namun benih-benih kehidupan berdemokrasi di Indonesia telah ada hampir pada semua suku, marga, kerajaan di Nusantara, hanya saja belum dapat disebut pasti tahun berapa demokrasi mulai berlaku di Indonesia.

Penggunaan demokrasi sebagai prinsip hidup bernegara telah melahirkan fiksi yuridis bahwa negara adalah milik masyarakat, dan fiksi yuridis ini melahirkan tolak tarik kepentingan, atau control, tolak tarik ini kemudian menunjukkan aspek lain yakni tolak tarik antara negara dengan masyarakat karena kemudian negara mengalami pertumbuhannya sendiri sehingga lahir konsep negara organis. ${ }^{9}$

Rumusan yang tercantum dalam Pembukaan UUD 1945 dapat dijadikan sebagai petunjuk yang jelas bahwa negara Indonesia adalah negara demokrasi (berkedaulatan rakyat) yang telah tertuang dalam Pasal 1 ayat (2) UUD 1945 bahwa "Kedaulatan ada ditangan rakyat yang dilaksanakan menurut Undang-Undang Dasar". ${ }^{10}$ Hal ini menunjukkan bahwa demokrasi Indonesia adalah demokrasi konstitusionil seperti dikemukakan oleh Miriam Budiardjo bahwa :

${ }^{6}$ J.C.T Simorangkir, Kamus Hukum, Jakarta : Sinar Grafika, 2000, Hlm. 36

${ }^{7}$ La Ode Husen, Negara Hukum, Demokrasi dan Pemisahan Kekuasaan, Makassar : PT. Umitoha Ukhuwah Grafika, 2009, Hlm.31

${ }^{8}$ Ibid, hlm 32

9 Moh.Mahfud MD, Demokrasi dan Konstitusi Di Indonesia, Studi tentang Integrasi Politik dalam kehidupan Ketatanegaraan, Jakarta : Rineka Cipta, 2000, Hlm.20

${ }^{10}$ Amandemen Ketiga UUD 1945 
Ciri khas dari demokrasi konstitusionil ialah gagasan bahwa pemerintah yang demokratis adalah pemerintah yang berbatas kekuasaannya dan tidak dibenarkan bertindak sewenang-wenang terhadap warga negaranya.Pembatasan-pembatasan atas kekuasaan pemerintah tercantum dalam konstitusi. ${ }^{11}$

Pada Hakikatnya terdapat tiga ide untuk menetapkan suatu sistem pemerintahan yang demokratis, yaitu:

a. Ide partisipasi, mengandung pengertian rakyat ikut serta dalam proses pengambilan keputusan dalam bidang politik dan bidang pemerintahan baik melalui perwakilan maupun secara langsung, dengan pernyataan pendapat bail lisan maupun tulisan yang harus dilindungi secara konstitusionil.

b. Ide pertanggungjawaban pemerintah terhadap rakyat berarti bahwa pemerintah harus mempertanggunbgjawabkan semua tindakannya kepada rakyat (accountability) sebab pemerintah melaksanakan fungsinya berdasarkan wewenang yang diberikan oleh rakyat.

c. Ide kesamaan, dalam ini kesamaan dalam demokrasi yang berarti kesamaan berpartisipasi dalam proses pengambilan keputusan dalam hukum dan pemerintahan. ${ }^{12}$

Dari uraian di atas menunjukkan bahwa dalam konteks Indonesia, demokrasi mengandung tiga arti, pertama, demokrasi dikaitkan dengan sistem pemerintahan dalam arti bagaimana caranya rakyat diikutsertakan dalam penyelenggaraan pemerintahan; kedua, demokrasi sebagai asas yang dipengaruhi oleh budaya, historis bangsa Indonesia sehingga muncul istilah demokrasi konstitusional; dan ketiga,demokrasi sebagai solusi tetantatif untuk menyelesaikan beberapa persoalan yang dihadapi dalam rangka penyelenggaraan negara sehingga lahir istilah musyawarah mufakat.

\section{Partai Politik}

Kata partai berasal dari kata part dalam bahasa Latin, yang berarti "bagian". Dalam kamus bahasa Inggris, kata party berarti pihak (misalnya dalam suatu perjanjian), even sosial (pesta), dan grup atau kelompok bersama.Berbeda dengan pengertian kata, partai (party) sebagai istilah umumnya tidak dibedakan oleh ilmuwan politik dari istilah partai politik (political party). Mereka mempergunakan kedua istilah ini untuk menunjuk entitas yang sama, yang mereka bedakan dari kelompok kepentingan (interest group) atau kelompok penekan (pressure group) yang tidak menjadi peserta dalam pemilihan umum. ${ }^{13}$

Secara umum dapat dikatakan bahwa partai politik adalah suatu kelompok yang terorganisir yang anggota-anggotanya mempunyai orientasi, nilai-nilai, dan cita-cita yang sama. Tujuan kelompok ini ialah untuk memperoleh kekuasaan politik dan merebut kedudukan politik dengan cara konstitusional untuk melaksanakan programnya. ${ }^{14}$

Menurut Pasal 1 angka (1) Undang-Undang Nomor 2 Tahun 2011 Tentang Partai Politik, yaitu Partai Politik adalah organisasi yang bersifat nasional dan dibentuk oleh sekelompok warga negara Indonesia secara sukarela atas dasar kesamaan kehendak dan cita-cita untuk memperjuangkan dan membela kepentingan politik anggota, masyarakat, bangsa dan negara, serta memelihara keutuhan Negara Kesatuan Republik Indonesia berdasarkan Pancasila dan Undang-Undang Dasar Negara Republik Indonesia Tahun 1945.

Sedangkan definisi partai politik menurut para ilmuwan politik, Carl Friedrich mengatakan bahwa :

Sebuah partai politik merupakan sekelompok manusia yang terorganisir yang stabil dengan tujuan merebut atau mempertahankan penguasaan pemerintahan bagi pimpinan partai dan berdasarkan penguasaan ini akan memberikan manfaat bagi anggota partainya, baik idealisme maupun kekayaan material serta perkembangan lainnya. ${ }^{15}$

Sigmund Neumann dalam buku karyanya Modern Political Parties mengemukakan bahwa:

\footnotetext{
${ }^{11}$ La Ode Husen, Op.Cit, Hlm.35

${ }^{12}$ Ibid, Hlm.36

${ }^{13}$ Ahmad Farhan Hamid, Partai Politik Lokal di Aceh, Jakarta : Kemitraan 2011, Hlm. 4

${ }^{14}$ Miriam Budiardjo, Dasar-Dasar Ilmu Politik, Jakarta:Gramedia Pustaka Utama 2013, Hal.404

${ }^{15}$ Inu Kencana Syafiie, Pengantar Ilmu Politik , Bandung:Pustaka Reka Cipta 2009, Hal.316
} 
Partai politik merupakan organisasi dari aktivitas politik yang berusaha untuk menguasai pemerintahan dengan merebut dukungan rakyat atas dasar persaingan dengan suatu golongan lain yang mempunyai pandangan yang berbeda. ${ }^{16}$

Sedangkan menurut Miriam Budiardjo:

Partai politik merupakan sarana bagi warga Negara untuk turut serta atau berpartisipasi dalam proses pengelolaan Negara. Dimana partai politik adalah suatu kelompok terorganisir yang anggotaanggotanya mempunyai orientasi, nilai-nilai, dan cita-cita yang sama. ${ }^{17}$

Dengan melihat beberapa defenisi diatas, kiranya dapat dipahami bahwa partai politik merupakan suatu organisasi yang ada dalam suatu negara yang menjalani ideologi tertentu dan dibentuk dengan tujuan khusus yang berusaha mencari dan mempertahankan kekuasaan dalam pemerintahan, baik melalui pemilihan umum dan cara-cara lain yang sah untuk mendapatkan dukungan umum.

Di negara demokrasi dalam hal ini Indonesia, partai politik dapat menjalankan fungsinya sesuai harkatnya pada saat kelahirannya yakni menjadi wahana bagi warga negara untuk berpartisipasi dalam pengelolaan kehidupan bernegara dan memperjuangkan kepentingannya di hadapan penguasa.

Adapun fungsi partai politik dapat dilihat dalam Pasal 11 UndangUndang Nomor 2 Tahun 2011, yaitu partai politik berfungsi sebagai sarana :

a. Pendidikan politik bagi anggota dan masyarakat luas agar menjadi warga Negara Indonesia yang sadar akan hak dan kewajibannya dalam kehidupan bermasyarakat, berbangsa dan bernegara;

b. Penciptaan iklim yang kondusif bagi persatuan dan kesatuan bangsa Indonesia untuk kesejahteraan masyarakat;

c. Penyerap, penghimpun, dan penyalur aspirasi politik masyarakat dalam merumuskan dan menetapkan kebijakan Negara;

d. Partisipasi politik warga Negara Indonesia; dan

e. Rekrutmen politik dalam proses pengisian jabatan politik melalui mekanisme demokrasi dengan memperhatikan kesetaraan dan keadilan gender.

Sedangkan menurut Miriam Budiardjo fungsi partai politik terbagi menjadi empat ${ }^{18}$, yaitu :

a. Sarana komunikasi politik. Arus informasi dalam suatu Negara bersifat dua arah artinya berjalan dari atas ke bawah dan dari bawah ke atas dan disinilah kedudukan partai politik dalam arus ini sebagai jembatan antara "mereka yang memerintah" dengan "mereka yang diperintah".

b. Sarana sosialisasi politik. Sosialisasi politik merupakan suatu cara untuk memperkenalkan nilai-nilai politik, sikap-sikap dan etika politik yang berlaku atau dianut oleh suatu Negara, partai, atau organisasi. Proses dimana seseorang memperoleh pandangan, orientasi, dan nilai-nilai dari masyarakat dimana ia berada, prose situ juga mencakup proses dimana masyarakat mewariskan norma-norma dan nilai-nilai dari satu generasi ke generasi berikutnya.

c. Sarana rekrutmen politik. Proses melalui dimana partai mencari anggota baru dan mengajak orang yang berbakat untuk berpartisipasi dalam proses politik.

d. Sarana pengatur konflik. Dalam Negara demokratis yang masyarakatnya bersifat terbuka adanya perbedaan dan persaingan pendapat sudah merupakan hal yang wajar. Tetapi dalam masyarakat yang sangat heterogen sifatnya maka perbedaan pendapat ini, apakah ini berdasarkan perbedaan etnis, status, sosial ekonomi atau agama, mudah sekali mengundang konflik. Pertikaian-pertikaian semacam ini dapat diatasi dengan bantuan partai politik. Sekurang-kurangnya dapat diatur sedemikian rupa, sehingga akibatakibat negatifnya seminimal mungkin. Namun dipihak lain, dilihat seringkali partai malahan mempertajam pertentangan yang ada.

Dapat dipahami bahwa pada level kenegaraan partai politik bekerja di dua lembaga negara, yakni legislatif dan eksekutif. Dimana partai politik dalam negara demokrasi merekrut calon-calon yang tepat yang akan maju dalam proses pemilihan umum. Partai juga berperan dalam seleksi kandidat yang akan diangkat

\footnotetext{
${ }^{16}$ Miriam Budiardjo, Dasar-Dasar Ilmu Politik, Jakarta:Gramedia Pustaka Utama 2013, Hal.404

${ }^{17}$ Ibid, hal 404-405

18 JimlyAsshiddiqie, Pengantar Ilmu Hukum Tata Negara, Jakarta : Raja Grafindo Persada, 2013,Hlm. 406-407
} 
sebagai pejabat politik apabila memperoleh kemenangan dalam pemilihan atau ikut dalam koalisi yang memerintah. Pejabat publik yang diusung partai yang menang, berwenang untuk mengangkat pejabat baru dalam kabinet dan posisi penting pengambil kebijakan lainnya dalam pemerintahan.

Sedangkan secara umum pada level masyarakat, partai politik mengajak dan/atau menerima orangorang menjadi anggota partai dan mengorganisasikan mereka hingga satuan pemerintahan terkecil, serta membantu kepentingan masyarakat.Partai politik dalam derajat yang berbeda-beda mengadakan pertemuan dengan anggota-anggota tersebut untuk menanamkan ideologi partai atau budaya partai, menyampaikan isu atau kebijakan, menerima dan menyampaikan masukan dari anggota dan masyarakat. Dengan begitu penting dalam sistem politik yang sedang berlangsung, maka sudah seharusnya apabila partai politik untuk selalu berusaha melaksanakan fungsifungsinya dengan baik, sehingga akan menghasilkan tujuan yang maksimal baik bagi partai politik itu sendiri atau bagi pemerintah dan rakyat.

Adapun tujuan partai politik menurut RamlamSurbakti dapat dibagi tiga, yaitu:

a. Partai Perwakilan Kelompok, artinya partai yang menghimpun sebanyak mungkin kelompok masyarakat untuk memenangkan sebanyak mungkin kursi di parlemen seperti Barisan Nasional di Malaysia.

b. Partai pembinaan bangsa, artinya partai yang bertujuan untuk menjaga keutuhan nasional dan biasanya menindas atau mengesampingkan kepentingan-kepentingan sempit, seperti Partai Aksi Rakyat di Singapura.

c. Partai Mobilisasi, artinya partai yang berusaha memobilisasi masyarakat kearah pencapaian tujuan-tujuan yang ditetapkan oleh pimpinan partai, sedangkan partisipasi masyarakat dan perwakilan kelompok cenderung bersifat monopolistis karena hanya satu partai dalam masyarakat. Partai Komunis di Negaranegara Komunis merupakan contoh dari partai mobilisasi. ${ }^{19}$

Hal tersebutlah yang membedakan partai politik dengan kelompok kepentingan lainnya.Partai politik selalu memperjuangkan suatu kepentingan dalam skala yang luas melalui mekanisme pemilu, sedangkan kelompok penekan atau kelompok kepentingan hanya mengejar kepentingan-kepentingan sesaat dalam ruang lingkup yang lebih kecil serta tidak melalui pemilu.

Partai politik menggalang dukungan warga negara yang berminat untuk berpartisipasi dalam kehidupan politik. Sumber daya yang dimiliki oleh partai politik terus menerus dikonsolidasikan untuk membangun solidaritas, memperkokoh komitmen untuk mewujudkan cita-citanya. Sebagai sebuah organisasi partai politik diharapkan mampu mengartikulasikan mengaggregasikan berbagai kepentingan dan memperjuangkannya untuk dikonversikan menjadi keputusan politik yang mempungaruhi berbagai aspek kehidupan bermasyarakat dan bernegara.

Tujuan partai politik selalu dicantumkan dalam anggaran dasarnya sesuai dengan Pasal 2 UndangUndang Nomor 2 Tahun 2011. Tujuan tersebut menuangkan apa yang hendak dicapai apa masa yang akan datang yang hendak diwujudkan bersama. Tujuan dijadikan pedoman dalam mengarahkan kegiatan partai politik dan berbagai sumbar legitimasi keberadaan partai politik serta menjadi sumber motivasi bagi masyarakat untuk mengidentifikasikan dirinya dengan partai politik yang bersangkutan.Tujuan partai politik berfungsi sebagai tolak ukur untuk menilai keberhasilan atau kegagalan para pemimpin partai politik.

Oka Mahendra menjelaskan bahwa:

tujuan partai politik pada dasarnya adalah keadaan yang dikehendaki yang senantiasa dikejar untuk diwujudkan di masa yang akan datang. Partai politik tentunya berupaya merumuskan tujuannya sedemikian rupa agar betul-betul aspiratif, mungkin dapat dicapai dan berorientasi ke massa depan yang lebih memberi harapan, mempunyai daya tarik yang kuat untuk membangun citra partai dan menggalang dukungan yang kuat. ${ }^{20}$

Sedangkan di dalam Pasal 10 Undang-Undang Nomor 2 Tahun 2011 tentang Partai politik dijelaskan bahwa Partai Politik mempunyai tujuan umum dan khusus yaitu :

1. Tujuan umum Partai Politik adalah :

a. mewujudkan cita-cita nasional bangsa Indonesia sebagaimana dimaksud dalam Pembukaan UndangUndang Dasar Negara Republik Indonesia Tahun 1945;

\footnotetext{
${ }^{19}$ Ramlan Surbakti, 1992 , Memahami Ilmu Politik, Jakarta,PT. Gramedia Widia Sarana Indonesia, Hlm 124.

${ }^{20}$ Oka MahendraSoekady, 2004, Prospek Partai Politik Pasca 2004, YayasanPancurSiwah, hlm.99
} 
b. menjaga dan memelihara keutuhan Negara Kesatuan Republik Indonesia;

c. mengembangkan kehidupan demokrasi berdasarkan Pancasila dengan menjungjung tinggi kedaulatan rakyat dalam Negara Kesatuan Republik Indonesia; dan

d. mewujudkan kesejahteraan bagi seluruh rakyat Indonesia

2. Tujuan khusus Partai Politik adalah :

a. meningkatkan partisipasi politik anggota dan masyarakat dalam rangka penyelenggaraan kegiatan politik dan pemerintahan;

b. memperjuangkan cita-cita partai politik dalam kehidupan bermasyarakat, berbangsa, dan bernegara; dan

c. membangun etika dan budaya politik dalam kehidupan bermasyarakat, berbangsa, dan bernegara.

Dapat disimpulkan bahwa untuk mencapai tujuan khusus partai politik sebagaimana telah diatur dalam Undang-undang tersebut, pelaksanaan pendidikan politik menjdi suatu hal yang amat penting.

\section{HASIL DAN PEMBAHASAN \\ Fungsi Partai Politik Dalam Memberikan Pendidikan Politik Bagi masyarakat Dan Konsekuensi Yuridisnya}

Menurut Aristoteles, manusia menjadi makhluk sosial (zoon politikon), manusia tidak dapat lepas dari kesatuannya ${ }^{21}$ dimana selama itu kita menemukan politik. Berdasarkan pendapat diatas dapat dikatakan bahwa setiap manusia sebagai makhluk sosial tidak akan lepas dari kegiatan-kegiatan politik seperti bagaimana kita menyatukan perbedaan-perbedaan dalam masalah pelaksanaan politik. Pada tataran ini , maka kesadaran politik warga negara menjadi faktor determinan dalam partisipasi politik masyarakat, artinya sebagai hal yang berhubungan denganpengetahuan dan kesadaran akan hak dan kewajiban yang berkaitan dengan lingkungan masyarakat dan kegiatan politik menjadi ukuran serta kadar seseorang terlibat dalam proses partisipasi politik, sehingga tujuan dari proses demokrasi dalam sebuah negara dapat terlaksana sebagaimana mestinya.

Henry B Mayo menyatakan bahwa: Demokrasi didasari oleh beberapa nilai yakni:

1. Menyelesaikan perselisihan secara damai dan melembaga

2. Menjamin terselenggaranya perubahan secara damai dalam suatu masyarakat yang sedang berubah

3. Menyelenggarakan pergantian pemimpin secara teratur

4. Membatasi pemakaian kekerasan pada tingkat yang minimum

5. Mengakui dan menganggap wajar adanya perbedaan, keanekaragaman (diversity)dalam masyarakat yang tercermin dalam perbedaan pendapat, kepentingan serta tingkah laku

6. Menjamin tegaknya keadilan. ${ }^{22}$

Dari pendapat diatas, dapat disimpulkan bahwa, hasil dari demokrasi adalah selain memilih pemimpin dengan rentang waktu yang teratur serta mampu mengatasi segala perbedaan yang lahir dari peroses demokrasi itu sendiri, serhingga dapat mewujudkan suatu keadilan yang dirasakan oleh seluruh masyarakat yang ada dalam sebuah negara. Maka idealnya demokrasi ini disalurkan melalui proses pemilu yang jujur dan bebas dari tekanan kelompok kekuasaan politik manapun.

Namun dalam setiap Pemilu, masalah Golongan Putih (Golput) sering menjadi wacana yang hangat dan krusial. Meski tidak terlalu signifikan, tetapi ada kecenderungan atau trend peningkatan jumlah Golput dalam setiap pemilihan. Bahkan Golput adalah jumlah terbesar di hampir setiap pemilihan di gelar.Sejatinya Golput adalah fenomena yang alamiah. Hanya saja, tentunya hal ini harus di batasi jumlahnya. Di hampir setiap pemilihan, jumlah Golput akan di anggap sehat jika jumlah Golput dalam kitaran 30 persen, meski banyak pemilihan jumlah Golputnya melampaui titik itu, mencapai kitaran 40 persen. Hasil survei dari LSI (Lembaga Survei Indonesia) merata-ratakan total partisipasi politik rakyat dalam Pilkada sekitar 60 persen atau dengan kata lain rata-rata jumlah Golput mencapai 40 persen. Besar kecilnyadan maksimal tidaknya jumlah golput akan sangat tergantung dari upaya yang dilakukan.

\footnotetext{
${ }^{21}$ Abu Daud Busroh, Ilmu Negara, Jakarta, Bumi Aksara, 2006, hal. 22

${ }^{22}$ Henry B Mayo , sebagaimana dikutip Sirajuddin, Dasar-Dasar Hukum Tata Negara, Malang, Setara Press, 2015, Hal.
} 
Dari pengamatan, hal-hal lain yang menpengaruhi tingkat partisipasi masyarakat dalam pemilu 2014 ialah; Pertama karena masyarakat belum terdaftar dalam Daftar Pemilih Tetap (DPT) enggan pergi ke kelurahan terdekat dan melapor agar bisa terdaftar sebagai DPT. Kedua karena para pemilih yang sudah mendapat undangan untuk mencoblos di daerahnya mempunyai urusan mendadak diluar kota atau sakit. Ketiga karena ada masyarakat yang menilai bahwa partai peserta pemilu tidak ada yang bisa menampung aspirasi para masyarakat dan caleg,capres dan cawapresnya tidak sesuai dengan kriteria mereka. Keempat tingkat ketidak percayaan masyarakat yang tinggi terhadap pemerintah sebelumnya yang menyebabkan mereka enggan pergi ke TPS untuk memilih. Kelima karena kurangnya kinerja pihak penyelenggara pemilu seperti KPU dan Banwaslu yang kurang meneliti DPT di daerahnya masing-masing. Dari kelima faktor yang menyebabkan golput pada tahun 2014, point keempat menjadi alasan yang cukup bagi masyarakat untuk memilih golput. mengapa masyarakat mulai tidak percaya pada pemerintah/elite-elite politik yang berada di MPR/DPR sana, disebabkan dari banyaknya pemberitaan-pemberitaan tentang skandal kasuskasus yang menimpa para elite politik tersebut, korupsi di berbagai kementrian makin menambah rendahnya tingkat kepercayaan masyarakat pada pemerintah.

Sehingga dalam pemilu 2019, diharapkan jumlah Golput dapat menurun secara signifikan, mengingat betapa berharganya sebuat suara untuk masa depan bangsa lima tahun kedepan. Oleh karena itu, untuk menumbuhkan kesadaran politik masyarakat, penting sekali bagi semua pihak berpikir cerdas dalam menyikapi kisruh dan konflik-konflik politik yang terjadi. Pada keadaan seperti inilah sangat dipahami pentingnya pendidikan politik bagi masyarakat, agar masyarakat menjadi pemilih yang cerdas dan dan dapat memberikan kesadaran masyarakat untuk tidak golput.

Partai politik yang merupakan sarana bagi warga negara untuk turut serta atau berpartisipasi dalam proses pengelolaan negara. Dinamika dan perkembangan masyarakat yang majemuk menuntut peningkatan peran, fungsi, dan tanggung jawab partai politik dalam kehidupan demokrasi secara konstitusional sebagai sarana partisipasi politik masyarakat dalam upaya mewujudkan cita-cita nasional bangsa Indonesia, menjaga dan memelihara keutuhan Negara Kesatuan Republik Indonesia, mengembangkan kehidupan demokrasi berdasarkan Pancasila sebagaimana termaktub dalam Pembukaan UUD Tahun 1945 dengan menjunjung tinggi kedaulatan rakyat dan mewujudkan kesejahteraan bagi seluruh rakyat Indonesia melalui pendidikan politik dan pengkaderan serta rekrutmen politik yang efektif.

Kantaprawira Rusadi menjelaskan bahwa: pendidikan politik adalah aktifitas yang bertujuan untuk membentuk dan menumbuhkan orientasi-orientasi politik pada individu. Pendidikan politik yaitu untuk meningkatkan pengetahuan rakyat agar mereka dapat berpartisipasi secara maksimal dalam sistem politiknya. Sesuai paham kedaulatan rakyat atau demokrasi, rakyat harus mampu menjalankan tugas partisipasi. ${ }^{23}$

Menurut Pasal 1 angka (4) Undang-Undang Nomor 2 Tahun 2011, pendidikan politik adalah proses pembelajaran dan pemahaman tentang hak, kewajibandan tanggung jawab setiap warga negara dalam kehidupan berbangsa dan bernegara. Selanjutnya dalam Pasal 13 huruf e dinyatakan bahwa: Partai politik diwajibkan memberikan pendidikan politik dan menyalurkan aspirasi politik anggotanya.

Kemudian dalam Pasal 31 Undang-Undang Nomor 2 Tahun 2011 tujuan dari partai politik dalam melakukan pendidikan politik bagi masyarakat. Pertama, meningkatkan kesadaran hak dan kewajiban masyarakat dalam kehidupan bermasyarakat, berbangsa, dan bernegara. Kedua, meningkatkan partisipasi politik dan inisiatif masyarakat dalam kehidupan bermasyarakat, berbangsa dan bernegara. Ketiga, meningkatkan kemandirian, kedewasaan, dan membangun karakter bangsa dalam rangka memelihara persatuan dan kesatuan bangsa. Dimana pendidikan politik tersebut dilaksanakan untuk membangun etika dan budaya politik sesuai dengan Pancasila.

Selanjutnya Pasal 34 ayat (3a) menjelaskan bahwa: dalam pelaksanaan pendidikan politik, partai politik mendapatkan bantuan keuangan yang bersumber dari Anggaran Pendapatan dan Belanja Negara/Anggaran Pendapatan dan Belanja Daerah yang diberikan secara proporsional kepada partai politik yang mendapatkan kursi di Dewan Perwakilan Rakyat, Dewan Perwakilan Rakyat Daerah Provinsi, yang

${ }^{23}$ Kantaprawira Rusadi, 2004. Sistem Politik Indonesia, Suatu Model Pengantar, Edisi Revisi, Sinar Baru Algensindo, Bandung. Hlm. 55 
penghitungannya berdasarakan jumlah perolehan suara. Bantuan keuangan tersebut diprioritaskan untuk melaksanakan pendidikan politik bagi anggota partai politik dan masyarakat.

Pendidikan Politik sebagaimana dimaksud ayat (3a) tersebut berkaitan dengan kegiatan :

a. Pendalaman mengenai empat pilar berbangsa dan bernegara, yaitu Pancasila, UUD 1945, Bhineka tunggal Ika dan Negara Kesatuan Republik Indonesia

b. Pemahaman mengenai hak dan kewajiban warga negara Indonesia dalam membangun etika dan budaya politik, dan

c. Pengkaderan anggota partai politik secara berjenjang dan berkelanjutan.

Dalam pelaksanaannya maka partai politik menerima bantuan anggaran baik dari APBN ataupun APBD, sebagaimana dalam Pasal 9 Peraturan Pemerintah Nomor 1 Tahun 2018 Tentang Perubahan atas Peraturan Pemerintah Nomor 5 Tahun 2009 Tentang Bantuan Keuangan Kepada Partai Politik, dinyatakan bahwa:

(1) Bantuan Keuangan kepada partai politik diprioritaskan untuk melaksanakan pendidikan politik bagi anggota partai politik dan masyarakat.

Maka dapat disimpulkan bahwa fungsi partai politik dalam pelaksanaan pendidikan politik ini, memiliki norma hukum yang jelas, dan telah diatur melalui berbagai instrument hukum berupa UndangUndang, Peraturan Pemerintah dan Instruksi Menteri. Sebenarnya tidak ada lagi alasan bagi partai politik untuk mengabaikan fungsi tersebut. Karena melihat pada kenyataan yang terjadi dilapangan fungsi ini sama sekali diabaikan oleh rata-rata elit politik yang tergabung dalam partai politik yang ada saat ini. Sehingga kesadaran masyarakat akan pentingnya proses politik dalam menentukan pemegang kekuasaan negara sarat dengan konflik dan kecurangan dalam berpolitik.

Pentingnya pendidikan politik ini, harus juga ditentukan dalam sebuah mekanisme program pendidikan politik ialah tata cara atau teknik penanaman atau pembentukan nilai-nilai politik yang telah ada dalam dirinya. Mekanisme dalam implementai kebijakan pendidikan politik biasanya dibuat standart operation prosedur (SOP), SOP nantinya menjadi pedoman bagi pelaksana program dalam bertindak . Agar dalam pelaksanaan kebijakan program pendidikan politik dari tujuan dan sasaran kebijakan.

Berdasarkan Instruksi Presiden Nomor 12 Tahun 1982 tentang Pendidikan Politik bagi Generasi Muda terdapat 3 mekanisme: Pertama, merupakan yang paling rendah dan lebih mudah untuk dicapai, yaitu dengan pengetahuan, dalam hal ini pengetahuan yang berhubungan dengan kesadaran politik. dalam istilah lain sering disebut cognitif morality. Kedua, berhubungan dengan masalah sikap (afektif). Pada tahap ini memerlukan lebih banyak usaha dan pematangan. Sedangkan tahap terakhir berhubungan dengan masalah perilaku atau tindakanyang dilakukan setelah seseorang mendapatkan pendidikan politik. ${ }^{24}$

Bentuk pendidikan politik menurut Rusadi Kartaprawira ${ }^{25}$ dapat diselenggarakan antara lain melalui:

1. Bahan bacaan seperti surat kabar, majalah, dan lain-lain bentuk publikasi massa yang biasa membentuk pendapat umum.

2. Siaran radio dan televisi serta film (audio visual media).

3. Lembaga atau asosiasi dalam masyarakat seperti masjid atau gereja tempat menyampaikan khotbah, dan juga lembaga pendidikan formal ataupun iniformal.

Pentingnya pendidikan politik ini juga di muat dalam Undang-UndangNomor 2 Tahun 2011, tentang partai politik, pasal 31 dikemukan partai politik melakukan pendidikan politik :

1. Partai politik melakukan pendidikan politik bagi masyarakat sesuai dengan ruang lingkup tanggungjawabnya dengan mempengaruhi keadilan dan kesejahteraan gender dengan tujuan antara lain:

a. Meningkatkan kesadaran hak dan kewajiban masyarakat dalam kehidupan bermasyarakat, berbangsa dan bernegara;

b. Meningkatkan partisipasi politk dan inisiatif masyarakat dalam kehidupan bermasyarakat, berbangsa dan bernegara; dan

\footnotetext{
${ }^{24}$ Instruksi Presiden Nomor 12 Tahun 1982 tentang Pendidikan Politik bagi Generasi Muda

${ }^{25}$ Kartaprawira Rusadi, Op.Cit, hal. 56
} 
c. Meningkatkan kemandirian, kedewasaan dan membangun karakter bangsa dalam rangka memilihara persatuan dan kesatuan bangsa.

2. Pendidikan politik sebagaimana dimaksudkan pada ayat (1) dilaksanakan untuk membangun etika dan budaya politik sesuai dengan pancasila.

Selanjutnya Dalam Peraturan Menteri Dalam Negeri Nomor 36 Tahun 2010, Tentang Pedoman Fasilitasi Penyelenggaraan Pendidikan Politik dinyatakan dalam Pasal 6 bahwa:

Fasilitasi penyelenggaraan pendidikan politik dapat diberikan terhadap kegiatan, antara lain:

a. seminar dan lokakarya;

b. sosialisasi dan diseminasi peraturan perundang-undangan;

c. asistensi, pelatihan dan bimbingan teknis;

d. pagelaran seni dan budaya;

e. jambore, perkemahan, napak tilas; dan

f. berbagai macam perlombaan seperti pidato, jalan sehat, cerdas tangkas, karya tulis ilmiah, film dokumenter, dan cipta lagu.

Berikutnya dalam Pasal 7 menyatakan bahwa:

(1) Kelompok sasaran fasilitasi penyelenggaraan pendidikan politik meliputi:
a. partai politik;
b. partai politik lokal;
c. organisasi kemasyarakatan;
d. lembaga nirlaba lainnya; dan
e. lembaga atau instansi vertikal di daerah.

Dapat disimpulkan bahwa, Partai politik yang merupakan salah satu subjek dari pendidikan politik, hal ini terkait fungsi dari partai politik itu sendiri menurut Pasal 11 Undang-Undang Nomor 2 Tahun 2011 Tentang Partai Politik, yang mana partai politik sebagai sarana pendidikan politik bagi anggota dan masyarakat luas agar menjadi warga negara Indonesia yang sadar akan hak dan kewajibannya dalam kehidupan bermasyarakat, berbangsa dan bernegara.Seperti yang di sebutkan dalam pasal 1 ayat (4) UU Nomor 2 Tahun 2011 tentang partai politik yang menyebutkan bahwa pendidikan politik merupakan proses pembelajaran dan pemahaman tentang hak, kewajiban, dan tanggung jawab setiap warga Negara dalam kehidupan berbangsa dan bernegara.

Menurut pasal tersebut jelas dikatakan bahwa partai politik memiliki fungsi memberikan pendidikan politik kepada setiap warga Negara dan seiap warga Negara juga berhak menerima pendidikan itu. Misalnya pendidikan politik yang diberikan oleh partai politik kepada masyarakat, disini partai politik memberikan pendidikan politik secara berkala kepada masyarakat. Dengan adanya pendidikan politik yang diberikan oleh partai politik, maka masyarakat mulai memahami apa itu politik dan pendidikan politik. Dengan adanya pendidikan politik yang diberikan, maka masyarakat juga akan dapat memberikan partisipasi yang tepatbagi negaranya, seperti berpartisipasi dalam memberikan suara pada pemilihan umum.

Maka, dalam rangka penguatan kelembagaan partai politik sebagai sarana pendidikan politik bagi anggota dan masyarakat luas agar menjadi warga negara Indonesia yang sadar akan hak, kewajiban dan tanggung jawabnya dalam kehidupan bermasyarakat, berbangsa, dan bernegara, maka bantuan keuangan kepada partai politik sebagaimana yang dimaksud diatas dialokasikan sebagai dana penunjang kegiatan partai politik untuk pelaksanaan pendidikan politik dan operasional sekretariat Partai Politik. Berdasarkan Peraturan Pemerintah Nomor 5 Tahun 2009 yang tidak memberikan batasan porsi penggunaan bantuan keuangan antara pendidikan politik dan operasional sekretariat partai politik, Namun PP Nomor 83 Tahun 1982 memberi batasan bahwa bantuan keuangan kepada partai politik yang digunakan untuk melaksanakan pendidikan politik bagi anggota partai politik dan masyarakat paling sedikit $60 \%$ (enampuluh per seratus).

Dengan adanya perubahan terhadap Peraturan Pemerintah Nomor 5 Tahun 2009, yang selanjutnya dengan ditetapkannya Peraturan Pemerintah Nomor 1 Tahun 2018 Tentang Bantuan Keuangan Kepada Partai Politik, dimana didalamnya diatur pula bahwa partai politik juga harus memprioritaskan pendidikan politik dari bantuan yang telah diberikan. Selanjutnya Peraturan Pemerintah Nomor 1 Tahun 2018 Tentang Bantuan Keuangan Bagi Partai Politik Menjelaskan Bahwa: 
Pasal 9:

(1) Bantuan keuangan kepada Partai Politik diprioritaskan untuk melaksanakan pendidikan politik bagi anggota Partai Politik dan masyarakat.

(2) Selain digunakan untuk melaksanakan pendidikan politik sebagaimana dimaksud pada ayat (1), bantuan keuangan kepada Partai Politik juga digunakan untuk operasional sekretariat Partai Politik.

Pasal 10 :

(1) Kegiatan pendidikan politik sebagaimana dimaksud dalam Pasal 9 berkaitan dengan:

a. peningkatan kesadaran hak dan kewajiban masyarakat dalam kehidupan bermasyarakat, berbangsa, dan bernegara;

b. peningkatan partisipasi politik dan inisiatif masyarakat dalam kehidupan bermasyarakat, berbangsa, dan bernegara; dan

c. peningkatan kemandirian, kedewasaan, dan membangun karakter bangsa dalam rangka memelihara persatuan dan kesatuan bangsa.

(2) Kegiatan pendidikan politik sebagaimana dimaksud pada ayat (1) dilaksanakan dengan memperhatikan keadilan dan kesetaraan gender untuk membangun etika dan budaya politik sesuai dengan Pancasila.

Kemudian dalam Pasal 12 A ayat (1) dan Pasal 18 A Peraturan Pemerintah tersebut mengamanatkan kepada Badan Pemeriksa Keuangan untuk membuat Peraturan BPK mengenai Tata Cara Penyampaian Laporan oleh Partai Politik dan Tata Cara Penyampaian Laporan Hasil Pemeriksaan oleh BPK kepada partai politik, paling lama 1 (satu) tahun sejak Peraturan Pemerintah tersebut diundangkan. Sehingga konsekuansi yuridis dari partai yang mendapatkan bantuan keuangan, diatur dalam :

Pasal 12

(1) Partai Politik wajib membuat laporan pertanggungjawaban penerimaan dan pengeluaran keuangan yang bersumber dari dana bantuan APBN/APBD.

(2) Untuk membuat laporan pertanggungjawaban sebagaimana dimaksud pada ayat (1), Partai Politik wajib melaksanakan pembukuan dan memelihara bukti penerimaan dan pengeluaran atas dana bantuan keuangan.

Pasal 13

Partai Politik wajib menyampaikan laporan pertanggungjawaban penerimaan dan pengeluaran keuangan yang bersumber dari dana bantuan APBN/APBD secara berkala 1 (satu) tahun sekali kepada Pemerintah setelah diperiksa oleh Badan Pemeriksa Keuangan.

Pasal 14

(1) Laporan pertanggungjawaban sebagaimana dimaksud dalam Pasal 13 disampaikan kepada:

a. Pemerintah melalui Menteri Dalam Negeri oleh Partai Politik tingkat pusat;

b. gubernur oleh Partai Politik tingkat provinsi; dan

c. bupati/walikota oleh Partai Politik tingkat kabupaten/kota.

(2) Laporan pertanggungjawaban sebagaimana dimaksud pada ayat (1) disampaikan paling lambat 1 (satu) bulan setelah diperiksa Badan Pemeriksa Keuangan.

\section{Pasal 15}

Laporan pertanggungjawaban sebagaimana dimaksud dalam Pasal 13 terbuka untuk diketahui masyarakat.

Pasal 16

Partai Politik yang melanggar ketentuan sebagaimana dimaksud dalam Pasal 13 dikenai sanksi administratif berupa penghentian bantuan keuangan APBN/APBD sampai laporan diterima oleh Pemerintah dalam tahun anggaran berkenaan.

Jadi konsekuensi yuridis terhadap pelaksanaan pendidikan politik bagi masyarakat oleh partai politik secara umum yaitu partai poltik yang menerima bantuan keuangan yang bersumber dari Anggaran Pendapatan dan Belanja Negara/Daerah yang digunakan sebagai dana penunjang pendidikan politik bagi kader dan anggota partai politik dan operasional sekretariat partai poltik diwajibkan untuk menyampaikan 
laporan pertanggungjawaban bantuan keuangan tersebut kepada Pemerintahsetelah diperiksa oleh Badan Pemeriksa Keuangan Negara.

Dan bagi partai poltik yang tidak menyampaikan laporan pertanggungjawaban tersebut akan dikenakan sanksi administratif berupa penghentian bantuan keuangan yang bersumber dari APBN / APBD sampai laporan pertanggungjawaban tersebut diterima oleh Pemerintah.

\section{SIMPULAN}

Dari hasil analisa yang dipaparkan sebelumnya, dapat disimpulkan bahwa Partai politik memiliki fungsi dalam melaksanakan pendidikan politik terhadap masyarakat, sehingga dapat membantu masyarakat yang cerdas dalam partisipatif politik, yang memiliki pengaruh yang sangat besar dan penting terhadap keberlangsungan kekuasaan pemerintahan lima tahun kedepan. Adapun konsekuensi yuridis terhadap pelaksanaan pendidikan politik bagi masyarakat oleh partai politik secara umum yaitu partai poltik yang menerima bantuan keuangan yang bersumber dari Anggaran Pendapatan dan Belanja Negara/Daerah yang digunakan sebagai dana penunjang pendidikan politik bagi kader dan anggota partai politik dan operasional sekretariat partai poltik diwajibkan untuk menyampaikan laporan pertanggungjawaban bantuan keuangan tersebut kepada Pemerintahsetelah diperiksa oleh Badan Pemeriksa Keuangan Negara.

\section{DAFTAR PUSTAKA}

Abdul Bari Azed, Pemilu dan Partai Politik Di Indonesia, Pusat Studi Hukum Tata Negara FH-UI, Jakarta, 2013.

Ahmad Farhan Hamid, Partai Politik Lokal di Aceh, Jakarta : Kemitraan 2011.

Inu Kencana Syafiie, Pengantar Ilmu Politik, Bandung:Pustaka Reka Cipta 2009.

Heru Nugroho,Pasar Dan Keadilan Sosial,2001.

J.C.T Simorangkir, Kamus Hukum, Jakarta : Sinar Grafika, 2000.

La Ode Husen, Negara Hukum, Demokrasi dan Pemisahan Kekuasaan, Makassar : PT. Umitoha Ukhuwah Grafika, 2009.

Moh.Mahfud MD, Demokrasi dan Konstitusi Di Indonesia, Studi tentang Integrasi Politik dalam kehidupan Ketatanegaraan, Jakarta : Rineka Cipta, 2000,.

Miriam Budiardjo, Dasar-Dasar Ilmu Politik, Jakarta:Gramedia Pustaka Utama 2013.

JimlyAsshiddiqie, Pengantar Ilmu Hukum Tata Negara, Jakarta : Raja Grafindo Persada, 2013.

Ramlan Surbakti, 1992 , Memahami Ilmu Politik, Jakarta,PT. Gramedia Widia Sarana Indonesia.

Oka MahendraSoekady, 2004, Prospek Partai Politik Pasca 2004, YayasanPancurSiwah.

Abu Daud Busroh, Ilmu Negara, Jakarta, Bumi Aksara, 2006.

Henry B Mayo, sebagaimana dikutip Sirajuddin, Dasar-Dasar Hukum Tata Negara, Malang, Setara Press, 2015.

Kantaprawira Rusadi, 2004. Sistem Politik Indonesia, Suatu Model Pengantar, Edisi Revisi, Sinar Baru Algensindo, Bandung.

Instruksi Presiden Nomor 12 Tahun 1982 tentang Pendidikan Politik bagi Generasi Muda 